\section{artelogie}

\section{Artelogie}

Recherche sur les arts, le patrimoine et la littérature de l'Amérique latine

12 | 2018

Idiosyncrasie de l'indigénisme en Amérique latine.

Pluralité des sources et des appropriations extra-

latino-américaines

\title{
Video 3- Entretiens d'Artelogie avec Karen Cordero Reiman.
}

Élodie Vaudry y Karen Cordero

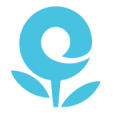

\section{OpenEdition}

Edición electrónica

URL: http://journals.openedition.org/artelogie/2664

DOI: 10.4000/artelogie.2664

ISSN: 2115-6395

Editor

Association ESCAL

Referencia electrónica

Élodie Vaudry y Karen Cordero, "Video 3- Entretiens d'Artelogie avec Karen Cordero Reiman. ", Artelogie [En línea], 12 | 2018, Publicado el 05 septiembre 2018, consultado el 15 septiembre 2020. URL : http://journals.openedition.org/artelogie/2664

Este documento fue generado automáticamente el 15 septiembre 2020.

Association ESCAL 


\section{Video 3- Entretiens d'Artelogie avec Karen Cordero Reiman.}

\section{Élodie Vaudry y Karen Cordero}

Este medio no se puede ver aquí. Por favor refiérase a la edición en línea http:// journals.openedition.org/artelogie/2664

\section{RESÚMENES}

Filmada por Élodie Vaudry a Karen Cordero en Ciudad de México, México. 